\title{
Urban Intensification as an Approach to Solve the Housing Problem in Egypt
}

\author{
"Proposed Mechanisms to Activate the Urban Intensification in the Executive \\ Reality"
}

\author{
Rehab Abd Allah Abd El Zaher \\ Assistant Lecturer, Department of Architecture \\ Faculty of Engineering, \\ Fayoum University, Egypt
}

\author{
Prof. Ehab Mahmoud Okba \\ Professor of Architecture and \\ Environmental Design Faculty of Engineering, \\ Fayoum University, Egypt
}

\author{
Prof. Mohga Emam Embaby \\ Professor of Architecture and \\ Faculty of Engineering, \\ Fayoum University, Egypt
}

\begin{abstract}
Since the 20th century and so far, the rates of the population growth have remarkably increased in Egypt in number and in terms of the populated land, which led to the need for good suitable land for construction to meet the increasing requirements of the increasing size of the population. Therefore, the process of urban intensification appeared as a result of the accelerating population growth rates (natural increase - migration) in urban areas than in rural areas and the resulting increase in constructional growth rate with limited local resources in an attempt to maintain agricultural lands, as well as to overcome the scarcity of land suitable for construction and meet the needs for housing, services, activities, and infrastructure. The automatic emergence of urban intensification by the population, which appears in the infringements whether in building illegal floors or horizontal expansion and the annexation of balconies and outer spaces such as in the city of Ain Al-Sira - Zenhom etc.

This indicates how this policy is appropriate to meet the needs of the population regardless of the violation registered later, till the strategic draft plans was issued which mainly aims at identifying urban properties and reduce urban crawling on agricultural land. Thus the study Amis to propose the approach of urban intensification as one of the best solutions to solve the housing problem in the current urban communities in Egypt at the theoretical and analytical level (strategic Plans) and to identify the obstacles that face the implementation of the policy, in addition it seeks to add proposed mechanisms to activate the policy of urban intensification to overcome the negative aspects and obstacles of its implementation.
\end{abstract}

\section{The Paper Methodology:}

1- The Theoretical Approach: introduce the most important intellectual principles, concepts - patterns - causes of intensification and how it is appropriate at the political level, planning, developmental, economic and environmental level.
2. The Analytical Approach: Analyze the urban intensification approach presented in the strategic plans to solve the housing problem and to present its role and significance, stages of implementation, requirements for its implementation in time, economically, environmentally and legally, and deducing the most significant negative effects and obstacles of implementation.

3 - Setting proposed mechanisms to activate the policy of intensification in the executive reality and to overcome the obstacles of its implementation in aspects for which housing studies were not presented in the strategic plans.

Keywords: Urban intensification; strategic plans; automatic and legislative intensification;sustainable. 


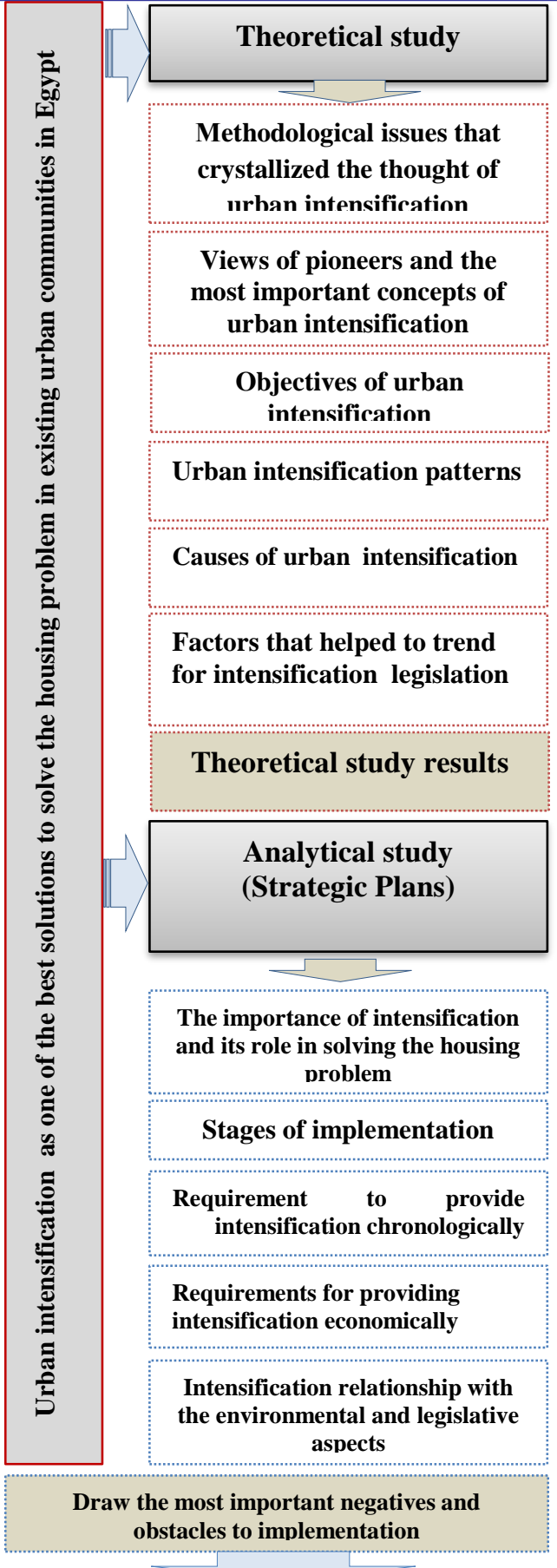

\section{Proposed mechanisms to activate urban intensification policies and overcome negatives}

Fig. 1- The Paper Methodology Source: The author

\section{INTRODUCTION:}

Most cities in the developing world suffer from severe lack of adequate housing units for their inhabitants. This is due to the increase in demand for housing from both a huge number of immigrants to the city as well as from the city residents searching for a new residence or wishing to move to a better district than the degraded areas in which they reside. Thus, most of the Egyptian cities grew during the 70 last years that has witnessed unequal and disorganized urban growth despite the fact that there are some general and structural plans of some Egyptian cities but those plans were not activated [1].

On the Author hand, the General Authority for Urban Planning has recently adopted a new strategy by setting many urban development plans for Egyptian cities using the strategic planning approach which offered solutions to the housing problem in Egypt, including the urban intensification approach (The paper subject).

The problem of the study is the lack of an effective role of urban intensification in the executive reality despite of the evidence of the strategic plans of the intensification approach as one of the most effective approaches in solving housing problem. This paper aims to draw the role and the significance of urban intensification policy in solving the housing problem at the theoretical level (politically, schematically , Socially, economically, and culturally) and at the analytical level (legislative, environmental, time, social) and then propose mechanisms to activate the policy of urban intensification in executive reality.

\section{THE BASIC CONCEPTS AND METHODOLOGICAL ISSUES THAT CRYSTALLIZED THE THOUGHT OF URBAN INTENSIFICATION:}

The two main issues were identified that pointed out the idea of urban intensification can be summarized in the following [2]

1 - Urban intensification is necessity due to the aggravation of the problem of funding and lack of financial resources ( economic deflation)

Governments at all levels suffer from the acute and apparent lack of available financial resources and sources of financing from one side and the rise in demand and pressures for further government intervention to supply facilities, infrastructure and the implementation of a number of financial management policies for a number of governments, as those policies aimed at reducing debt burden and the amount of loans and local debt from the public budget and the Finance Ministry to finance facilities and infrastructure projects. Therefore there was a need to turn to urban intensification to solve the funding crisis, the need to economic contraction by reducing investment expenditures and achieve a degree of economic savings to reduce supply facilities, services and infrastructure as far as possible.

2 - Urban intensification to solve problems resulting from future urbanization crisis according to impacts of modern technology and global economic transformations and their urban implications, which lead to more intensification to more construction intensification to reduce the power of expansion and urban fragmentation of the territories. 


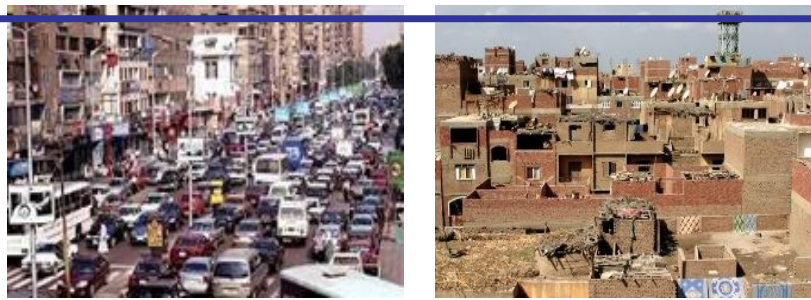

Fig. 2 - The spread of automatic urban intensification both horizontally and vertically in Egypt, source: Urban Intensification Approach to Control Urban Crawling on rural urban margins in the Main Urban Regions, Bayoumi, Walid Nabil Ali. 2000

\section{VIEWS OF PIONEERS IN URBAN INTENSIFICATION AND THE MOST SIGNIFICANT CONCEPTS:}

A number of pioneers identified intensification as a policy. [3]

- Sharaf ( Lord Mayer) identified intensification as a counter policy that face and constrain by emphasizing the optimum utilization of the present facilities, services and construction as well as the Author positive outcomes of intensification.

- Robert Stirson asserted the same previous trend which identified that political intensification to control the urban sprawl and increase in the use of public transport means and reduce the use of private cars

- Alan Mayne argued that the intensification policy In the present building block is due to the possibility of meeting the needs and providing future housing expansion within the borders to reduce the attitude towards residential expansion and the rapid urbanization in the rural urban margins which is expected to continue. Therefore, we should work on reversing those trends and limiting marginal growth. He also considered that intensification is that policy aimed at reducing human settlement and ownership of houses in the suburban areas and put limits on the growth of urban regions outside the cities.

- Stewart Smith - considered intensification policy as a policy and means at the same time for the inclusion of many of the population within the present residential areas where buildings are available and basic services, and also a counter policy for the present orientations built on many economic and social justifications by establishing new communities on the outskirts and suburbs.

- Lord Mayer found that it is an anti-process policy to the urban crawling provided that basic services are available.

- Carol Mills reached to the conclusion that intensification is aimed at the best exploitation of limited and shrinking and limited urban resources.

\section{URBAN INTENSIFICATION OBJECTIVES:}

The targets of urban intensification can be classified into:

Economic objectives:

- Increasing the use of urban resources available including land - urbanization - services - and enhancing them for intensify their use.

- Increasing investment spending to support and improve the level of living in the suburbs.

Urban objectives:
- Urban intensification to raise the level of urban densities and reduce the forces of counter-urbanization and urban spread.

- Controlling urban sprawl and reducing its rate to reduce the expansion and growth of urban sprawl at the expense of the countryside and agricultural land.

Housing objectives:

- Increasing the opportunities of choosing housing units and buildings to suit all needs.

- Increase housing densities.

Social objectives:

- Reducing social inequalities, isolation and reducing social separation of the urban poor in the suburbs.

- Achieving socio-social expansion among all social and economic groups.

Environmental objectives:

- Reduce urban growth and the expansion of suburbs at the expense of agricultural land.

- Optimal utilization of the present environmental resources.

- Reducing the pollution resulting from the use of means of transportation via reducing the rate of daily travels .There is a direct effect of vertical intensification on the environment as high densities save open green areas in addition to maintaining agricultural land.

\section{URBAN INTENSIFICATION PATTERNS:}

There are two types of urban intensification : Horizontal intensification and vertical intensification which include demolishing and intensification of buildings, Here is an overview about each type [4]:

A- Horizontal intensification : The increasing demand is on land for housing and the emergence of many illegal and informal land divisions and the establishment of several buildings in addition to the following reasons:.

* High demand for housing units (Residential apartments.)

* Low rates of building new houses by real estate contractors.

* Decrease in land prices in marginal areas (compared to high prices in the city which are characterized by the availability of great distances of land).

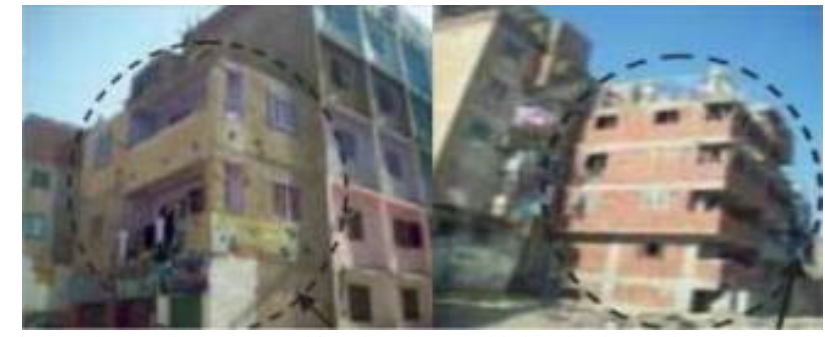

Fig.3- Photos shows Intensification by combining horizontal spaces to the building to meet the needs of the population, source: Population-Based Solutions to solve the Housing Problem Through Expansion, D. Kamal Mahmoud Kamal Jiblawi.

B- Vertical intensification: due to the rapid higher land prices on one hand, and the rise of construction and the cost of building medium- height buildings. Thus it was 
necessary to multi- floor buildings and raises the existing building according to the structural characteristics of each building and its constructing structure, as well as the available material resources of the owner and demand for housing.

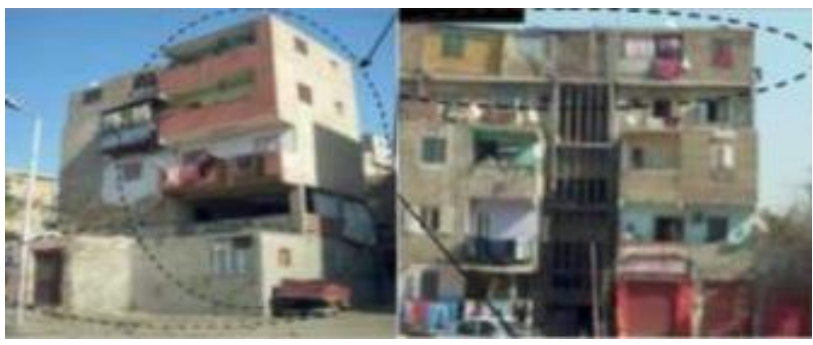

Fig.4- Vertical Intensification by increasing the number of Floors on the existing building to meet the needs of the population , source: PopulationBased Solutions to solve the Housing Problem Through Expansion, D. Kamal Mahmoud Kamal Jiblawi

\section{REASONS FOR URBAN INTENSIFICATION:}

\section{Political and legislative reasons:}

Specific political and legislative reasons to resort to the process of urban intensification in Egypt are:

- The massive destruction caused by the war changed many areas, either by removing them and reconstructing them on the modern style, or changing land use or developing it and constructing round roads, and improvising new roads within the old fabric. [5]

- The impact of revolutions, the socioeconomic changes, and social mobility affected the requirements of investment within the various urban areas, leading to the exploitation of all the available land within the area.

- Encouraging many politicians to the intensification policy to address the resulting schematic issues from the process of crawling and marginal growth [6]

- The state centralized policy which led to an increase in population density resulting from the concentration of services in major cities such as government circles, institutes, and factories. This resulted in attracting population and high migration rates from villages to cities, and thus led to an increased request on land and an increased on land trespassing, resulting in an increase in the prices of land accompanied by an increase in population density. The result was an increase in construction density and a decrease in services a change in the built and constructed environment.

- The number of bodies participating in the management of urbanization whose approval is required when issuing building licenses (Civil Aviation Authority - Antiquities Authority - Directorate of Agriculture - National Authority for Civil Protection - ....), in addition to a great number of laws that are handled when managing urbanization ( Local Administration Act - The desert Protection Act - the law of Antiquities Protection - Law on the protection of agricultural land) that will be discussed in the Urban Management Study [7].

- Building heights are handled by various laws so that they do not exceed 1.5 of road width to provide healthy climate for residential units and to remain unchangeable and flexible for those heights.
- No densities are defined in any of the laws regulating urbanization until the issuing of the law of Urban Planning No. 3 of 1982. These densities remained until issuing Building Law No. 119 of the year2008

- Consequently, the previously mentioned disadvantages we see that the Department of Urbanization do not properly control the current urban bloc and thus lead to a lot of violations such as urban expansion on the agricultural land, and turning to the process of randomly urban intensification to overcome the scarcity of the available land for construction and to meet the deficit and the need for services( housing ). In addition, to achieve the maximum utmost possible benefit from economically valuable.

\section{Reasons for auto growth:}

Intensification is a phenomenon that accompanies regional growth and the change of its basic structure. The change in the construction pattern occurs gradually and is accompanied by gradual change in densities. Urban change is a gradual change gradually occurs in varying degrees due to the effect of the time factor within a fixed special limit to meet the needs of the target population [8].

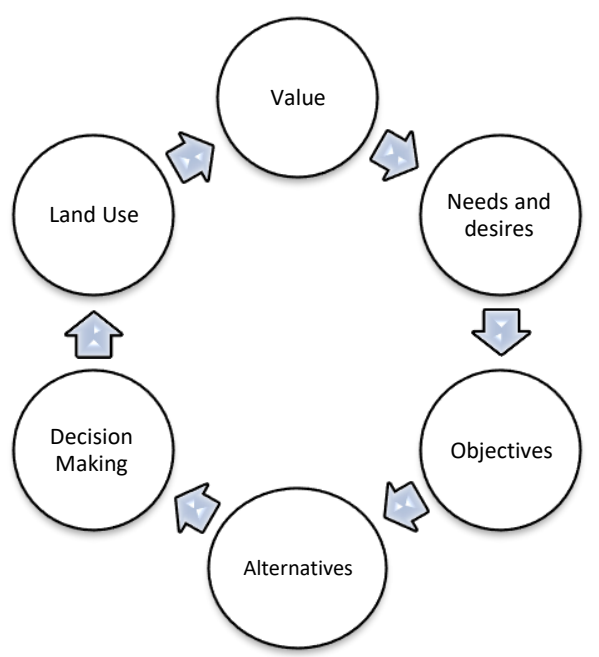

Fig 5- auto growth Stages source, Shaima Mahmood Ali, Master Thesis, Controlling the management of land use structure, faculty of Engineering, Cairo University, 2008.

\section{Social and demographic reasons:}

The emergence of settlements for the urban poor people and slum with low status as opposed to well- serviced residents supplied with facilities and services as a result of many different ecological operations[9]..

Changes occurred in social and demographics structures that have affected the increasing demand on housing (as units - housing lands and the consequent scarcity of land within the urban bloc) .Overcoming this problem began by urban intensification Hence, the most significant demographic factors that changed are:

- Changes in the family structure and the speed of disintegration of the family and break down.

- The increasing rates of composing small families (Nuclear family).

- Demographic changes such as natural increase in numbers of population and social and behavioral change. 
- Change in the internal relations between family members that was reflected on changes in the architectural shape of the building such as closing balconies, or building skyscrapers, or adding more rooms to the house.

- Migration from the countryside to the cities in hope of a better economic social level of living, and, as a result, cities were overcrowded in many of the random housing areas inhabited by industry workers, and marginal occupation.

The impact of demographic changes (family structure
change) on the growing demand for housing and the
need for intensification

Fig.6- The impact of demographic changes on the increasing demand for housing and the need for intensification ,source, Urban Intensification Between Automatic and Legislation, Ahmed, Hiba Mamoun Hamid, 2013.

\section{Economic reasons:}

There are several economic reasons that affect the process of urban intensification that can be summarized as follows:

- The cost of providing the services and facilities.

- Offer and demand on the lands and housing units and its connection with estate market.

- Lob opportunities.

- The economic level.

- The availability of funding.

- Identifying the best economic capacity of a group of users is vital to point out the optimizing size of the users. We mean by the economic capacity here the total agreed capacity. As their capacity for spending on a service increase, the number of users should be reduced and as their capacity for spending on a service decrease, this shortage of spending should be compensated by increasing the number of users of this service[10].

- The crisis of the available financial resources, for the developing countries and its effect on the application of urban intensification.

\section{Reasons related to development:}

The issue of constant development and the controversy about the patterns and urban structures capable of responding and interacting with the considerations of lasting urban development are significant, as it has been shown that the pattern of dense urban and integrated groupings of work, trade, and services supported by public means of transport are the best method to achieve the lasting urban development(urban intensification ), this is achieved by:

The closeness of the different urban elements ( housing, work, services) to the greatest degree to shorten the travelling distance and reduce the consumption of energy and environmental pollution in addition to strengthening the existing services and intensifying activities and services by reducing the establishment of employment centers, services and new business while raising the efficiency of the existing centers[11].

6. Construction reasons:

Construction reasons are one of the most important reasons that affect the process of urban intensification since it includes several aspects which is the change in land use, service centralization and communication led to the emergence of marginal groupings, and with natural determinants of horizontal extension land the scarcity of constructible land, as well the change in decisions and legislation and the absence of detailed urban plans as follows:

- Changing land use

- Centralization of services

- Communication

- There are natural parameters for horizontal expansion

- Limited land suitable for construction within the urban bloc changes decisions and legislation

- There are no urban detailed plans and plans.

\section{CASE STUDY THAT REFLECTS THE APPEARANCE OF URBAN INTENSIFICATION CONSISTENTLY BY USERS:}

Table 1- Case study Nasr city
Source: adopted by Author

\section{Cairo Governorate Nasr City: Site location \& Reasons for selection:}

Nasr City is located in the Republic of Egypt, Cairo Governorate. The study is in the western region of Nasr City, particularly in the sixth district of Al-Maham Street and the stadium area of Nasr Street.

This area was chosen because it is considered to be one of the areas where urban intensification has been observed, with a significant urban transformation.

\begin{tabular}{|l|l|}
\hline \\
$\begin{array}{l}\text { Location of Nasr City } \\
\text { Google map photo }\end{array}$ & $\begin{array}{l}\text { Location of Nasr City: } \\
\text { Google Earth }\end{array}$ \\
\hline
\end{tabular}




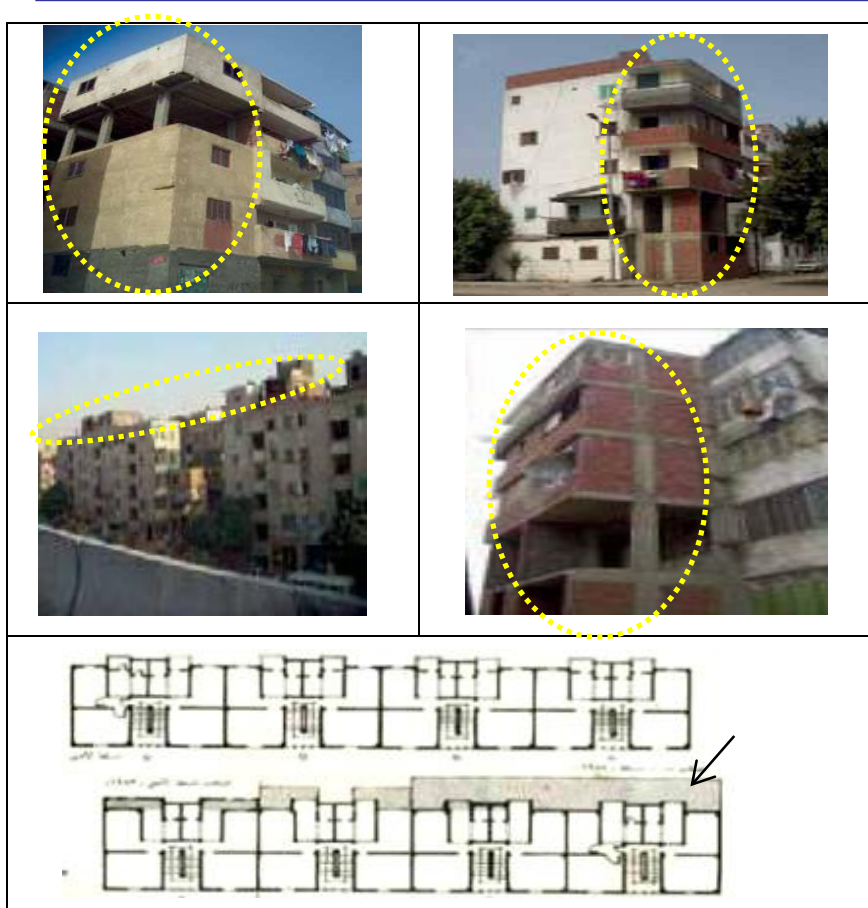

As shown in the pictures selected for West Nasr City the emergence of intensification by the population to provide housing needs to increase the area of apartments in buildings, which reflects the presence of intensification to solve the problem of housing disadvantage in existing urban communities in Egypt.

\section{URBAN INTENSIFICATION AS ONE OF THE BEST SOLUTIONS TO SOLVE THE HOUSING PROBLEM IN THE EXISTING URBAN COMMUNITIES:}

The urban intensification approach has been applied according to the legislation in large-scale urbanization projects in the Egyptian villages whether to provide the demand for housing and disability in various services. Two different forms of intensification were used: horizontal intensification or vertical intensification (especially in the supplying the lack in educational and health services). Also, it was used in projects of new urban communities or planned areas, whether modern or previously planned areas and are being modernized. There are several important factors that have helped in the progress of the process of intensification by legislation and formulating laws for urbanization. This is what we are going to discuss in the following discussion .

\section{First: - The political aspect:-}

Means slowing down the population mobility and encouraging much Population to settle and reside in the existing bloc, as well as activate the attractions factors instead of moving to the urban margins or suburbs. This can be done via the optimal use and exploitation of available financial resources Facilities and Services. Thus urban intensification has therefore been used politically as a way to face urban crawling and marginal growth resulting from the increase in the size of population and the corresponding weaknesses in the state resource to face the increase in the exploitation of facilities, services and infrastructure to meet the needs of the population on the one hand and to reduce Investment expenditures and supply costs of such services and facilities provided to new urban areas in the suburbs new urban communities on the other hand.

\section{Second: The development Aspect:}

Urbanization is considered one of the means to achieve continuous development aimed at creating more sustainable patterns especially around business centers(trade, business and employment centers), and around transportation centers and public transport axes, taking into consideration the implementation of public and basic principles of development through determining the requirements and planning controls of urban intensification in Planned Urban areas.

\section{Third: Planning Aspect:}

Intensification is used through legislation in the planned existing areas (both vertical and horizontal) to provide the population`s need for housing and services in the current areas in a way that suits the nature of the areas and the spatial privacy of the place concerning its character, structure and socioeconomic structure. As for the new communities, intensification is used in setting plans for new cities or villages as a method of determining the population sizes, drafting the budget for using the land, and the different housing Levels

\section{Fourth: The Social Aspect:}

Where Intensification is used as a tool for social integration, where it integrates housing groups to reduce the spatial social separation, as well as supporting and strengthening Facilities, services and infrastructure to improve standards of living and support society and social life.

\section{Fifth: - The Economic Aspect:}

As intensification was used economically so as to overcome the scarcity of constructible land in the Egyptian world, in addition to providing the demand for housing is especially for the average and low income population as a result of higher land prices and the corresponding rise in prices of housing units which does not suit with the economic situation of a large segment of Egyptian citizens. Also intensification is used as an economic method to deal with the lack in the financial resources of the state in the provision of facilities, infrastructure, and services to the new low income categories.

\section{RESULTS OF THE STUDY OF URBAN INTENSIFICATION AT THE THEORETICAL LEVEL:}

- Urban intensification emerged as a result of the exacerbation of the problem of funding and to solve the problems of urban expansion.

- Urban intensification has been defined from many pioneers as a policy against urban sprawl( e.g. Report \& 
Lord May), providing the needs for housing and future expansions (Alan Mayne) as well as the optimal exploitation of resources and available possibilities.

- The aims of urban intensification are summarized in economic, urban, housing, and social goals.

- Urban intensification includes two pattern : The horizontal whose emergence is reflected in crawling on the agricultural lands and vertical pattern which result mainly from the rapid population growth rates with the consumption of the majority of the land and the spots that can be built. Thus the price of the land went high and they resort to Vertical intensification .

- There are seven main reasons contributed to the emergence of urban intensification in the urban communities; are legislative reasons - reasons of natural growth - socioeconomic reasons - economic reasons reasons related to development - and -urban reasons).

- Urban intensification is the most suitable solution to solve the housing problem in urban communities in every aspect (political -Development - Planning - Social economic development).

\section{URBAN INTENSIFICATION (AT THE ANALYTICAL LEVEL) STRATEGIC PLANS:}

Before reviewing the approaches in solving housing problems in the strategic plans housing studies should be reviewed in the strategic plan as it included:

1. Introduction to the study of housing that include: the significance of the study and the general and detailed objectives and their relation to the scheme

2. Methodology of housing study:

2.1 The current situation: is divided into

A - Residential use ratios and residential buildings during the urban survey.

B - Dimensions of the problem of housing (quantity and quality) via the statistical data and urban survey.

c. Housing characteristics and housing conditions through the statistical Data and Urban Elevation.

2.2 Possibilities and determinants of providing housing needs.

A) The supply of housing units.

B) Available land and land prices.

(C) Temporary and unofficial housing.

D - Replacement and renewal areas in the city (deteriorating regions)
5. Areas of intensification .

F. Obstacles to the provision of housing

2.3 Key issues and cross-sectorial issues

2.4. Quadratic analysis of the shelter and slum sector

2.5 The development strategy for the housing sector addresses:

A - Estimating the future absorptive capacity

B Setting a program for housing sector: A summary of the study methodology can be presented in Fig. 7 


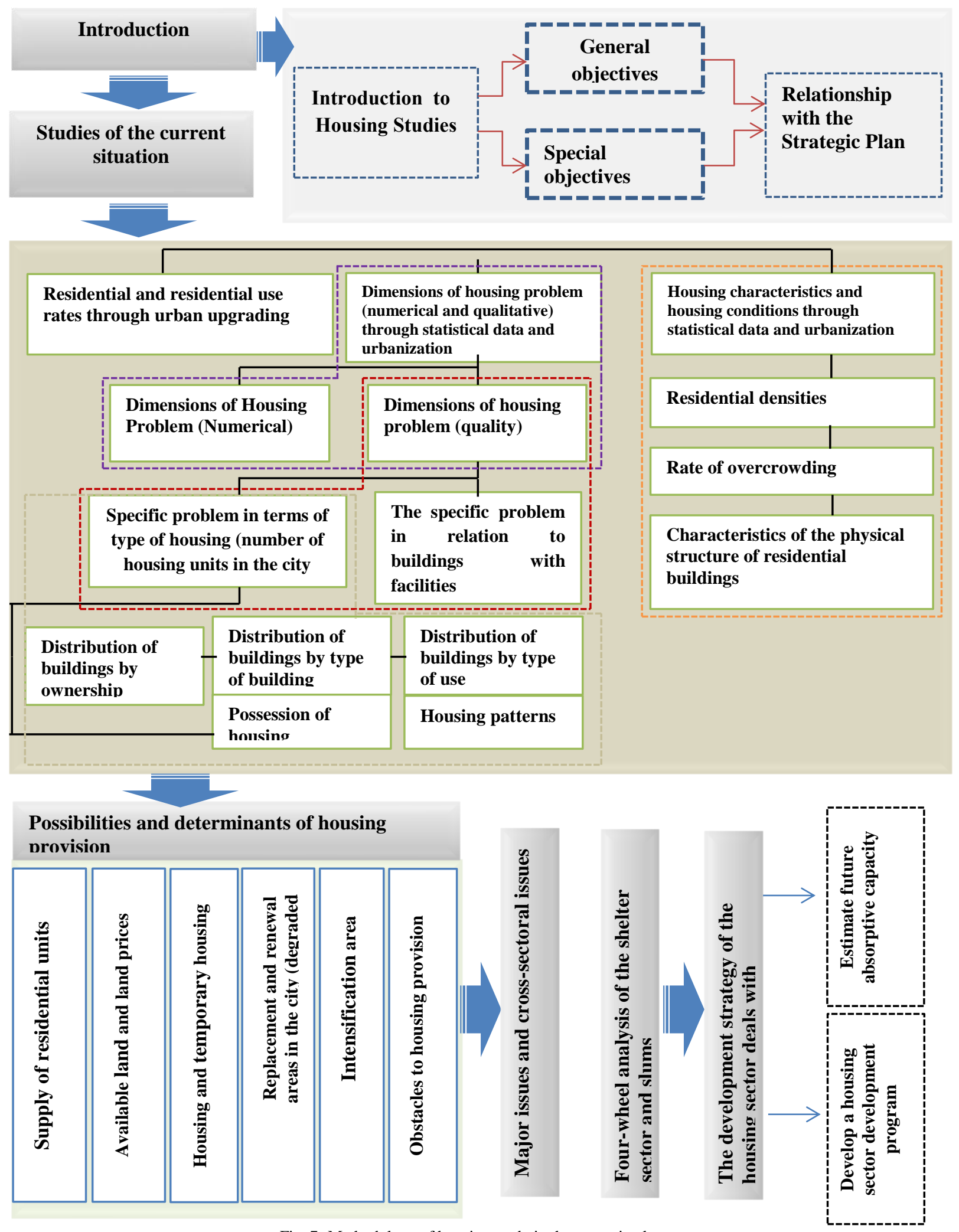

Fig. 7- Methodology of housing study in the strategic plans. Source: The author 


\section{EVALUATION OF THE URBAN \\ INTENSIFICATION APPROACH TO SOLVE THE HOUSING PROBLEM IN STRATEGIC PLANS:}

The strategic plan has succeeded in developing approaches to solve the housing problem in Egypt (possibilities to providing the needs for housing as presented in housing studies) which is considered one of the most important issues and problems facing the Egyptian society, as the housing sector is considered the main pillar for any urban or rural community in which the ratio of housing uses occupy the largest proportion of urban bloc. The concept of the housing sector extends to include in addition to providing the necessary housing units providing services, facilities, infrastructure and developing the construction and local economic development projects in order to achieve a sustainable healthy and safe urban environment. In the next section of the research paper, an approach of urban intensification in terms of its role and significance in providing residential units, stages and requirements of economic and time for implementation, as well as its relation to the environmental and legislative aspects. Then, obstacles that face implementation and hinder making use of urban intensification are drawn to effectively solve housing problems and then suggest mechanisms that contribute in overcoming these obstacles according to the following Methodology:

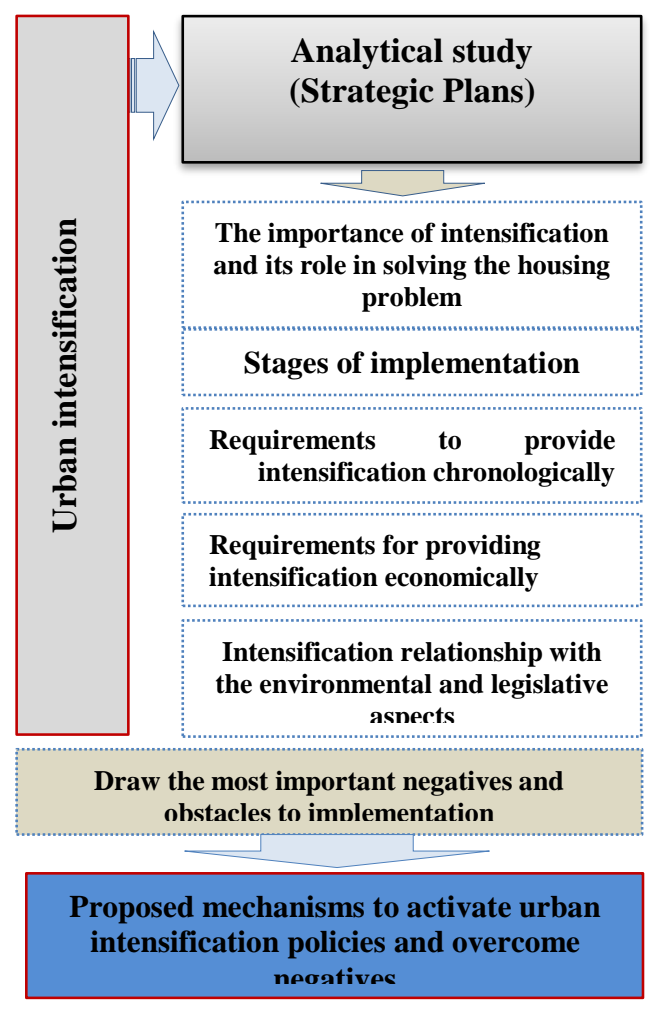

Fig. 8- Evaluation of the urban intensification Approach to Solve the Housing Problem in strategic plans, source: the author

\section{$\underline{\text { Urban intensification in strategic plans: }}$}

Horizontal intensification arises as a result of the low prices of land in marginal areas (compared to their high prices in the city characterized by the availability of constructible and accessible land spaces in great distances that are linked with a network of means transportation with an access to the various services and facilities that provide employment and job opportunities in construction and commercial services Sector) described by the strategic plan as integrating land space and agricultural spots within the existing urban mass[13].

Vertical intensification also arises as a result of the quick rise in prices of land and the rise in construction prices as well as the costs for medium height buildings. Thus it was necessary to build a number of floors and raise the present buildings high according to the structural characteristics of each building re-structuring the available material resources to the owner and the demand for housing.

\section{A-The role and significance of urban intensification for the proving housing units:}

- The strategic plan showed that urban intensification , vertical and Horizontal, provides the largest number of housing units to meet the needs of the population which reflects the importance of urban intensification and its role in solving the problem, as illustrated by the following tables[11]:

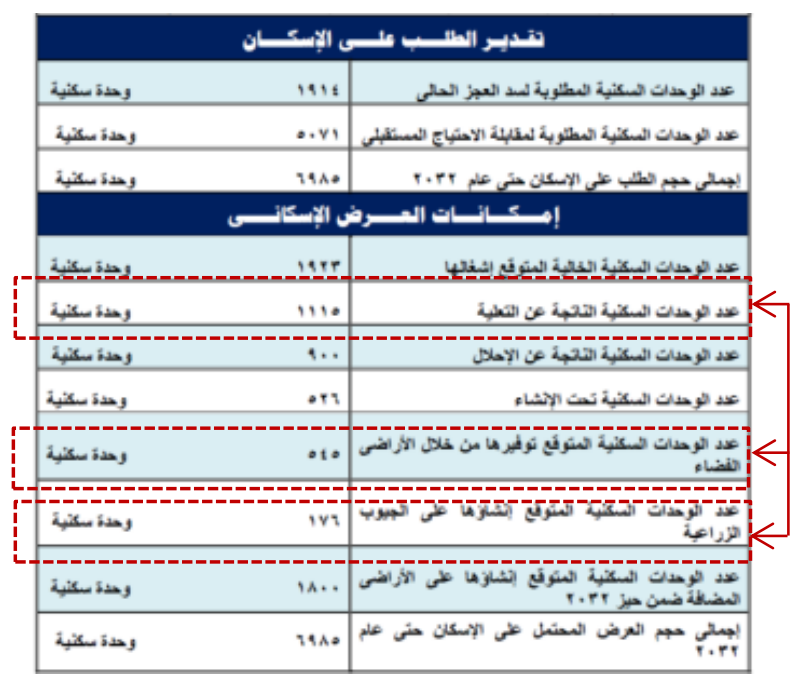

Fig.9 - Al-Balina strategic plan Al Balina City, Source: Sohag Governorate, Setting Urban Strategic Plans for Small Cities Ministry of Housing, Utilities and Development- General Urban Planning Authority, United Nations Program for Human Settlements. 


\begin{tabular}{|c|c|}
\hline القبشة (وددة سكنبة) & البيان \\
\hline 9104 & عدد الوددات العالية \\
\hline 0941 & 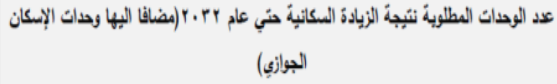 \\
\hline 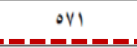 & 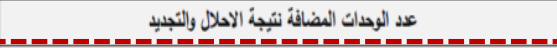 \\
\hline min & عد الودات المضافة للتعثبف الرأسي \\
\hline$r \leqslant$ & علد الودات المضافة من مشروع الإسكان \\
\hline 1910 & عدد الودات المكنة على الإراضي الفضاء دذلز العتلة الحالبة \\
\hline răt & 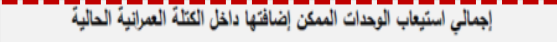 \\
\hline r991 & عد الودات المطلوية عي اراضي فضاء جلبدة \\
\hline
\end{tabular}

Fig.10 -Al- Hasina Strategic Plan, source: Al-Husseiniya City, Sharqiya Governorate, Preparing Urban Strategic Plans for Small Cities Ministry of Housing, Utilities and Development- General Urban Planning Authority, United Nations Program for Human Settlements.
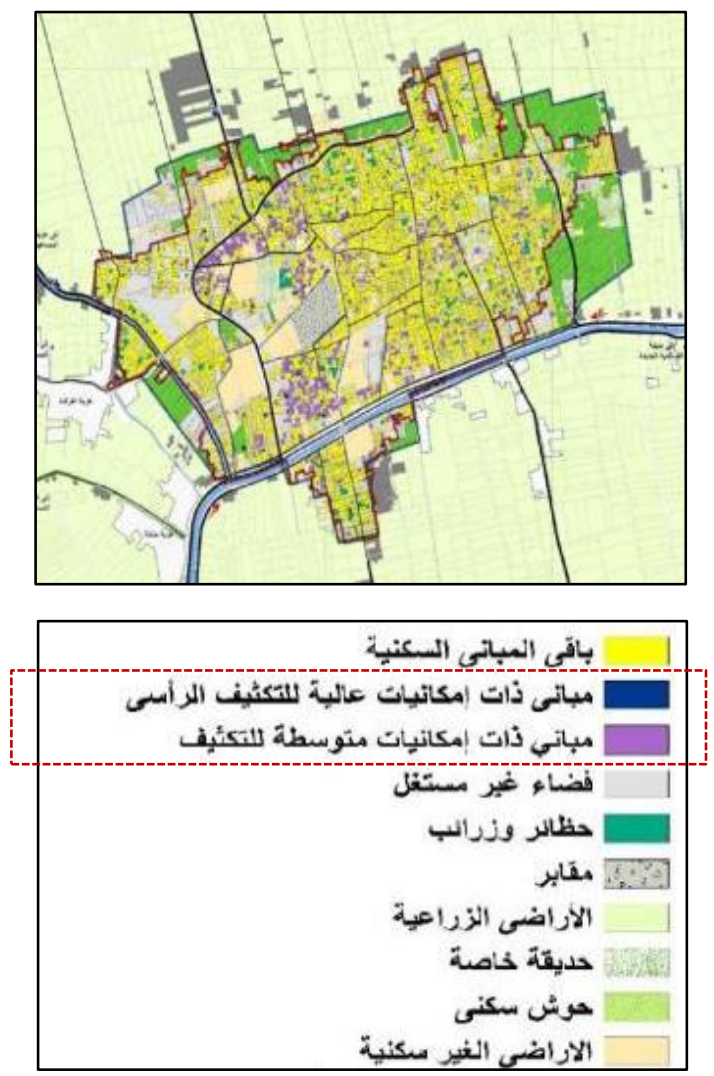

Fig.11 - intensification area in Al Hasina city

total units added from the vertical and horizontal intensification of the strategic plan of the city of Al-Balina [11] and Al-Hasina [12] where the total number of units added to Al Balina city is 1836 housing units and the city of Hasina about 2181 housing units which shows that the units provided by urban intensification is the most numerous compared to other approaches provided by the strategic plan.

\section{D-The implementation stages of urban intensification :}

The stages of intensification by legislation as mention in the strategic plans are:

Stage1: specific construction requirements are established in the urban area in terms of identifying the height and public densities of construction, and kind of uses ... etc. since the emergence of the urban region.

Stage 2: There is increased demand for the urban region in terms of providing housing, services, or some sort of activities, therefore a need for providing them emerges.

Stage3: Urban environment, economic, and social studies are carried in the region. A detailed outline of the region is done by raising the densities in line with the studies carried on the regions and the conditions defined by the laws, and then new conditions for the region are set for the existing urban area [14]

B-Requirements to provide intensification chronologically: Compared to the approaches that were raised in the strategic plan through replacement, urban renewal, and an approach to expansion projects. The urban intensification is carried out using the existing facilities, services and infrastructure, as well as the optimal exploitation to meet the needs of the population from one hand and to reduce investment and service costs, facilities and infrastructure network on the other hand. Therefore, it does not need a long time compared to the requirements of implementing the previous two approaches (replacement and renewal approach , expansion projects)] [24], as complete networks of infrastructure and services must be established, as well as the requirements of the replacement approach and the urban renewal of the resettlement of the population during the replacement.

\section{$C_{-} \quad$ Requirements for providing intensification economically:}

In the strategic plans the intensification was used as an economic method to deal with the low level of state financial resources in the provision of facilities and infrastructure for the new communities especially for the limited income categories.

One important factor that effect on intensification area in the strategic plan is the land prices, where the strategic plan showed the rise in land prices in the centers of the city from the parties.

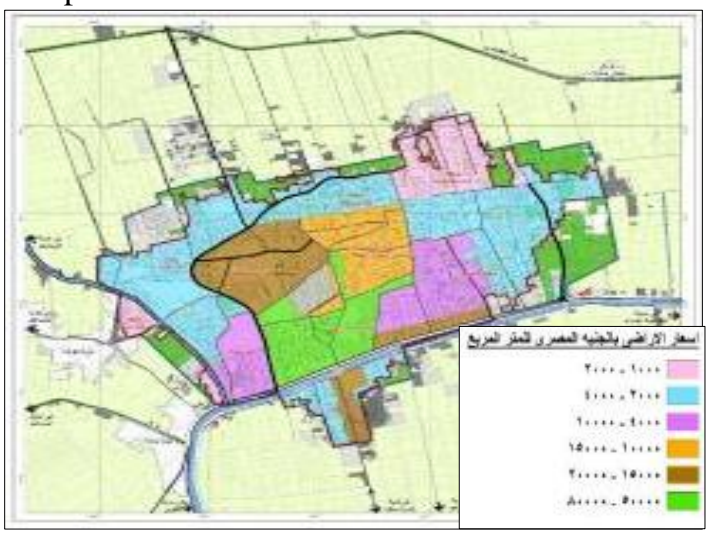

Fig.12 land price in Al- Hasina Strategic Plan.

On the other hand intensification has been used to make use of areas with high economic returns such as night façades. In this case, vertical intensification is used for the 
exploitation of land located on the banks of the rivers as these are limited and of high economic value High.[15]

E-The relationship of urban intensification to environmental aspects:

There is a direct effect of vertical intensification on the environment where high densities help to provide open green areas in addition to saving agricultural land because the continuous expansion and urban crawling of cities and villages will continue to devour agricultural land.

On the other hand the use of intensification through horizontal expansion is a way that provides positive empty spaces which are common spaces that give the city a special taste and concept, in terms of "gathering tracks places for activities.) Also, the orientation towards urban development patterns with high density will result in reduced rates of consuming energy and fuel, especially gasoline, which reduces the amount of gas emissions and the reduction of global warming and air pollution. Intensification results in the reduction of travelling and private transport trips to the least degree as much as possible, which reduces the amount of emissions not more than $5 \%$ of its current size .[16]

Urban intensification improves access to the work centers, trade and services in secondary centers in the suburbs by means of public transport particularly for low-income people to maintain the environmental resources while achieving the optimal exploitation of resources.

It is contributes to stopping crawling on agricultural land and the preservation of agricultural wealth through developing the present urban areas. Urban intensification is used as a tool for social integration, as it integrates the housing categories to reduce spatial social separation and supporting the facilities, services, and infrastructure that improve the standard of living and strengthen the society and community life, etc.

\section{F-The relationship of urban intensification with legislative aspects:}

Urban intensification is not specified in the regulated laws of construction till the issuing of the urban planning Law No. 3 in the year 1982, in the second half of the twentieth century. Thus it took a formal form where rates of public density were set, population density and construction density. Laws have evolved and rates for urban intensification have changed to be in line with the political, developmental, planning and economic situation of the state and in accordance with the requirements of real estate market and real estate investments till we have come to the unified Building Law No. 119 of 2008 as presented in detail (reasons for Urban intensification, political and legislative reasons). As for how far this law is implemented and its executive regulations, violations did not stop but the 1970s and early 1980s saw a rapid expansion in the movement of urbanization which made the task of this legislation difficult in organizing urbanization despite the increase of penalties stipulated in the law 109/1979 [17]
The urban intensification approach has been applied by legislation in large-scale urbanization projects in the villages of the Arab Republic of Egypt whether to provide the demand for housing and meet the deficit in various the services. Two different forms of intensification have been used; horizontal intensification or vertical intensification [27] [18].

\section{$G^{-}$Obstacles to the implementation of urban} intensification:

- The funding crisis and lack of financial resources and their urban implications on the necessity of intensifying development of the existing construction.

- The special urban character of the distinct urban areas is considered a determinant of the process of intensification where it should be placed within studies that precede the implementation process.

- The need to take into account the avoidance of negatives which may be caused by urban intensification of visual pollution in the existing urban areas and the noise that may lead to audio pollution, as well as taking into consideration the rate of overcrowding when setting a strategy for developing the housing sector using urban intensification

- The non-flexibility of laws and conditions of the existing regions in dealing with urban intensification in terms of Highs, road offers, and others.

- Housing studies on the approaches of solving housing problems in strategic planning to study infrastructure, road and transport networks and their capacity not comprehensive.

- Relationship of service centers and activities with urban intensification regions.

\section{THE FOLLOWING ARE SUMMARIZE OF PROS AND CONS OF INTENSIFICATION FROM THEORETICAL AND ANALYTICAL STUDIES:}

Table 2 source: the Author

\section{The pros of urban intensification}

1. One of the most important policies and approaches to provide the needs of the population was the use automatic intensification by the population, where they built more floors or horizontal expansion of residential units without any interference from the state or the government which indicates the appropriateness and easiness of this policy.

2. The strategic scheme pointed out that horizontal urbanization and vertical urbanization provides the largest number of housing units to meet the needs of the population, reflecting the significance of urban intensification and its role in solving the problem 
3. Intensification is used as a tool for social integration as it integrates housing groups to reduce social spatial separation, while supporting facilities, services, and infrastructure that improve the living standards and supports the society and community life

4. Urban intensification has been used politically as a method of combating urban crawling and marginal growth resulting from increased population and the corresponding decrease in the state resources to face this increase in utilization of facilities, services and infrastructure and the optimal exploitation of facilities to meet the needs of the population on one hand and to reduce investment expenses and supply costs services and facilities on the other hand.

5. In terms of development, urban intensification is considered one of the means to achieve sustainable development aimed at achieving more sustainable patterns around business centers (trade, business centers and employment) - around transport node and public transport axes taking into consideration the realization of the basic principles of sustainable development through the identification of the provisions and planning conditions for urban intensification in planned or target areas.

6. There is a direct effect of vertical intensification on the natural environment as high densities help to provide open green areas as well as agricultural land

7. On the other hand, intensification is used via horizontal expansion: One of the ways that lead to positive empty places and public spaces that give the city a special taste and notion, in terms of (gathering points - tracks places of activities concentration).

8. The approach to urban development patterns of intensity will reduce energy consumption rates especially gasoline, which reduces the volume of gas emissions and reduce global warming and air pollution

9. Intensification reduces trips and private transport to the least amount as possible, therefore it reduces the volume of gas emissions to not more than $5 \%$ of its current size.

\section{The Cons of Urban Intensification}

1- The crisis of funding, lack of financial resources, and their implications on the need to intensify the development of existing construction.

2- The special architectural character of current distinct urban areas should be placed within the implementation process.

3- Visual pollution of the current urban areas and noise that may lead to audio pollution, and rate of crowding should be taken into account when setting a strategy for developing the housing sector using urban intensification

4- The non- flexibility of laws dealing with urban intensification for each spatial range.

\section{PROPOSED MECHANISMS TO ACTIVATE THE APPROACH OF URBAN INTENSIFICATION IN THE EXECUTIVE REALITY :}

Targeted mechanisms have been developed and classified according to their goals into the following:

\section{1 - Services and infrastructure:}

1- Studying the assimilation of services for the future housing balance resulting from the development of the housing sector by using urban intensification and their spatial relationship in the added residential units.

2. Linking the study of the current status of the road network (regional and local) with the study of rates of transport and traffic, accidents and places of traffic jams , and the rate of flights on the city's local intranet in places of urban intensification.

3. Examining the extent and relevance of the proposals for the improvement of suggested road and transportation projects strategic plan of the city with capacity and adequacy of road and transport network for future moving of added housing units and population density, resulting from the development of the housing sector through urban intensification

4. Comprehensive housing studies for nutrition projects by using water, sanitation projects, and solid waste disposal projects of the future deposit resulting from the development of the housing sector through urban intensification

5- Studying the location of the served places and not serviced places of the infrastructure network and services and how to deal with this problem, as well as the role of development and future development projects in cover the future population density resulting from the development of the housing sector by urban intensification , The following figure shows the relationship between the future balance resulting from the development of the housing sector using urban intensification and the availability of infrastructure and services networks. 


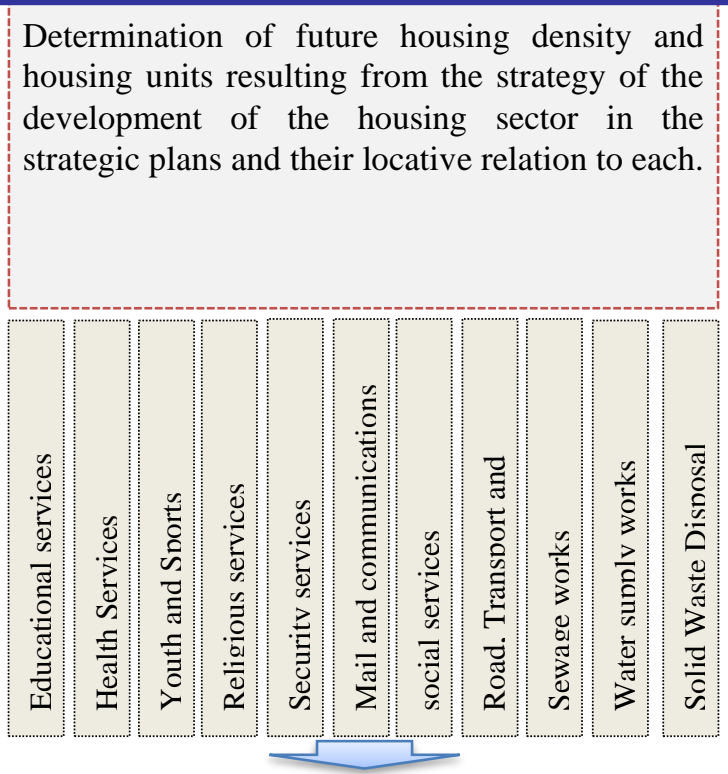

Extent of absorption of services, infrastructure of units and density of housing resulting from the policy of urban intensification.

Fig.13. proposed services studies to current housing study, source : The author

\section{2 -Urban character:}

6. Examining the effect of intensification on the general character of the proposed areas which should be taken into account, as successful experiences of urban intensification have demonstrated in cities such as Melbourne (Australia) [18] .
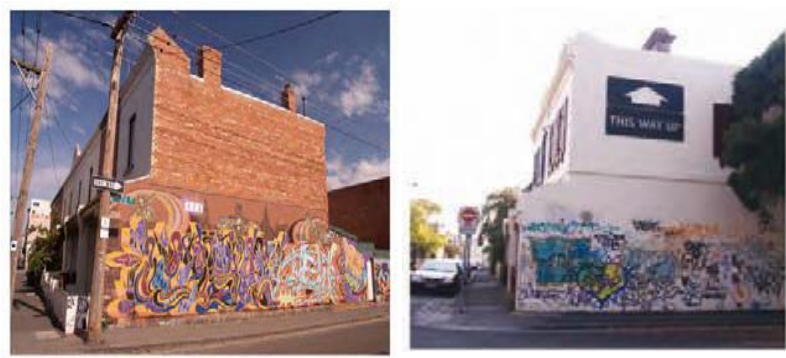

Fig.14 Melbourne (Australia) character, source: The character of urban intensification, A Report on research projects funded by the Australian Research Council, 2002-2010 Kim Dovey \& Ian Woodcock Faculty of Architecture, Building \& Planning University of Melbourne.

Examining the social factors and the user's acceptance of the idea of urban intensification, as the experience of Melbourne illustrates the extent of interest of planners and designers in the opinion of the population.

The population refused the idea of urban intensification so as not to cancel the spirit and character of some neighborhoods in the city while an opinion poll succeeded in accepting the idea of urban intensification of the city of Melbourne (Australia).
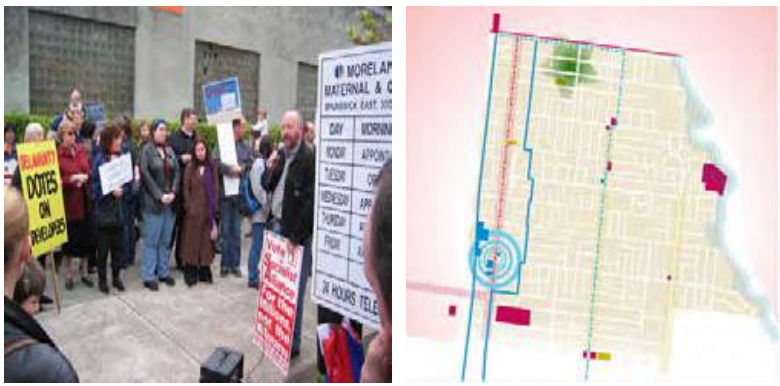

Fig. 15- A referendum for the population to accept the idea of urban intensification of the city of Melbourne (Australia).

Residents protest to carry out urban intensification in some areas of the city for the specific character of the place.

\section{3-Economic level:}

7. Setting up a well-studied plan to link land prices with areas of urban intensification and the extent of the impact of growing land prices on the process of urban intensification .

8. Improving the rental market to ensure that low - income people get the housing units (keeping balance between the rights of renter and owner, simplification of contracts and reduction of taxes, forcing rapid evacuation of renters when necessary, and adopting electronic rental systems)

9. Studying the extent to which economic feasibility is achieved for poor communities and providing job which ensures the stability of urban intensification areas and raises the yield and return on the economic activity at the national level.

10. Cooperation between the private sector and the public sector to provide funding for urban intensification and providing effective financing tools such as the Development Fund for Urban Regions which works on developing deteriorating regions.

\section{4 - Social level:}

11. Achieve community cohesion and economic, social and environmental security, as well as ensuring the population settlement in their original locations.

12. The need for user participation in decision-making before policy makers and officials get to the housing units at an economic, social and residential level.

\section{5 -Sustainable development:}

13- Examining the visual, auditory and environmental pollution that may result from intensification in unsuitable areas in this approach.

14 - Commitment to continuous maintenance of the units resulting from urban intensification policy and treatment of construction defects, lack of services and imposing fees in the tenancy contract. 
15. Achieving continuous development aimed at establishing more sustainable patterns especially around the trading centers (trade, business and employment centers) , around transportation nodes, and public transport axes taking into account the realization of the general and basic principles for sustainable development through defining the requirements and planning constraints.

16. Improving access to trade centers and services in secondary centers in the suburbs by means of public transport, especially for low-income people.

17. The necessity of taking into account providing green spaces and calculating the percentage due to each individual.

18. Achieving the optimal use of land and balance in functional relationships for land use and the distribution of investment services.

19. Decreasing the use of private means of transportation and thus reduces road accidents and use public transport means to reduce traffic and air pollution.

20. Reduce the level of poverty and unemployment by providing jobs near to the housing units that suit workers and the available skills that are considered to be the basic factors for attracting population to intensification areas and ensuring stability of those communities.

\section{Results and Recommendations:}

Urban intensification has been shown to achieve sustainable development as it includes the optimal utilization of the existing land resources, urbanization, services and supporting them to intensify their use.

In addition, it reduces travelling rates with easy access to service centers.

Urban intensification aims to control urban crawling and reduce its rates to control urban expansion and the growth of marginal random gatherings at the expense of rural and land.

Its effectively contributes in reducing social inequalities and social isolation of the urban poor in the suburbs, as well as achieving balanced social expansion among all socio-economic groups.

Urban intensification is economically to overcome the scarcity of constructible land in the Egyptian populated land, besides meeting the demand for housing especially for the average and low - income people due to the rise in land prices and the corresponding rise in the prices of housing units, which does not suit the economic status of a large segment of individuals in the Egyptian society.

Vertical Urban intensification appeared largely as a reaction to enforce the laws of agricultural land violation (horizontal intensification ).
All factors, whether legislative, developmental, social, demographic, economic, urban, etc. led to the emergence of urban intensification starting from the automatic and even the legislative. The theoretical study proved that urban intensification is more appropriate approaches to solve the problem of housing in urban communities in Egypt. This paper presented the methodology of housing studies in the strategic plans and is divided into:

-Introduction to housing studies- studies of the current situation, potentialities and determinants of housing studies- key issues and cross-sectorial issues, and the strategy of developing the housing sector.

The emergence of automatic intensification by the population shows the ease and convenience of the urban intensification approach to solve the housing problem in the existing urban communities.

There is a need to add more housing studies in the strategic plans with the correlation between intensity of services, basic buildings, and road network and service centers.

We should take into account the future housing density resulting from intensification operations and linking them with the development projects that were put forward in the strategic plans for each of the water supply, solid waste disposal, sanitation works and all development projects in all the items. The economic, geographic, and environmental evaluation of urban intensification section in the strategic plans showed its appropriateness to solve the housing problem in urban communities, without overlooking the user's role and participation because of its impact at the social, economic and urban levels. Urban intensification contributes to the exploitation of facades and areas such as the night water-facades and thus achieving high economic returns for those areas.

There is a need to develop an integrated system linking the current housing literature and mechanisms for activating intensification policy to ensure the right implementation of the policy so as to avoid the pros of the disadvantages.

\section{REFERENCES:}

[1] Mustafa Hussein Ajami, Legislative Aspects Of architecture and urbanization in Sustainable Development plans, Study of the Effect of Legislation and Laws on Sustainable urban Development from local World Realities Master, Faculty of Engineering, Al-Azhar University, 2015.

[2] Urban Intensification Approach to Control Urban Crawling on rural urban margins in the Main Urban Regions, Bayoumi, Walid Nabil Ali. 2000 . p 335.

[3] Urban Intensification Between Automatic and Legislation, Ahmed, Hiba Mamoun Hamid, 2013, p21.

[4] Population-Based Solutions to solve the Housing Problem Through Expansion, D. Kamal Mahmoud Kamal Jiblawi, 138, p. 2016.

[5] Salwa Khalil Youssef, Master, Change Dynamics and Deterioration in Classic valuable residential areas Faculty of Engineering, Cairo University, 2005 ,76 p.

[6] Shura Council, Services Committee - Preliminary Report On Unplanned housing in Slum in The Arab Republic of Egypt, 1664 . 
[7] Central Agency for Mobilization and Statistics - Census General Population and Establishments 2006

[8] Mohamed Fathi Mohamed Aref, Ph.D., Methods of Controlling land use, college of Engineering Tanta University, 2001.

[9] Ahmed Khaled Allam, Legislation for Urbanization, The AngloEgyptian Library, 1986

[10] Khaled Mahmoud Abu Baker Hussein : Applied Laws to Building requirements as an Approach to the management of urbanization In the Egyptian cities - PhD thesis - Al-Azhar University, Faculty of Engineering -2009.

[11] Al Balina City , Sohag Governorate, Setting Urban Strategic Plans for Small Cities Ministry of Housing, Utilities and Development- General Urban Planning Authority, United Nations Program for Human Settlements.

[12] Al-Husseiniya City, Sharqiya Governorate, Preparing Urban Strategic Plans for Small Cities Ministry of Housing, Utilities and Development- General Urban Planning Authority, United Nations Program for Human Settlements.

[13] Ahmed Khaled Allam, legislation governing urbanization , The Anglo-Egyptian Library, 1986, p3.

[14] Lawrence Berklin, translated by Syed Abdulkarim, Economics of Supply and Demand, Anglo Library, Cairo, 1987, p. 71

[15] Shaima Mahmood Ali, Master Thesis, Controlling the management of land use structure, faculty of Engineering, Cairo University, 2008, p. 22

[16] Nasr Said Nasr, Egypt's Agricultural Geography - Agricultural Development and Horizontal Agricultural Expansion - Said Raafat Library, Cairo, 1988 p

[17] The Effect of economic factor on change of Uses, Source Abdu Rahman Makhlouf, Description of the City, Cairo, 1998, p 119

[18] the character of urban intensification, A Report on research projects funded by the Australian Research Council, 2002-2010 Kim Dovey \& Ian Woodcock Faculty of Architecture, Building \& Planning University of Melbourne.

[19] Guide to the work of the general strategic plan for cities, Egyptian Ministry of Housing, Utilities and Communities General Authority for Urban Planning p. 1 -2

[20] Detailed plans for the Current Egyptian cities, Obstacles to implementation and proposals for solutions, MA, . $28 \mathrm{p}$

[21] The Alberos city IN of Kafr El-Sheikh Governorate, The Preparation of Urban Strategic Plans for Small Cities Ministry of Housing, Utilities and Development Authority - General Urban Planning the United Nations Program for human Settlements

[22] Du'aa Muhammad Mahmud al-Sharif, Ph.D., Sustainable Management of the Urban environment in Developing Countries, Faculty of Engineering, Cairo University, 2003, p. 48

[23] Salwa Khalil Youssef, MA Thesis, The dynamics of change and Deterioration in Classic Urban Valuable residential Regions, Faculty of Engineering, Cairo University 38, p. 2005,

[24] Khalid Mahmoud Abu Bakar Hassan: Applied Laws For Building Provisions as an Approach to the management of urbanization in the Egyptian Cities PhD thesis - Al-Azhar University Faculty of Engineering.

[25] Urban Intensification Between Automatic and Legislation, Ahmed, Heba Maamoon Hamid, MA Thesis, 2013 pp. 3

[26] Emad Al-Masri, Evaluation of the Development of Empty Urban Places in contemporary Arab civilization, A PhD dissertation, Faculty of Engineering, Urban Planning Department Ain Shams University, 1990.

[27] Mahmoud Taha Mahmoud Salim, Adjusting the Discrepancy between the unified Egyptian Law of Building height and the Law of Building Density No. 119, 2008 the Scientific Bulletin for Urbanization Sciences, Faculty of Urban Planning, the 11th issue, January 201 